\title{
Reviewers
}

In addition to members of the Editorial Board, we sought reviews from a number of other scholars. We wish to acknowledge our appreciation to all those who returned reviews during 2010.

Lenneke Alink

Jack Bates

Theodore Beauchaine

Joann Benigno

James Blair

Michelle Bosquet Enlow

Mara Brendgen

Patricia Brennan

Gene Brody

Jaqueline Bruce

Mandi Burnette

Keith Burt

Kristin Buss

Stephanie Carlson

Jude Cassidy

Tony Charman

Laurie Chassin

Douglas Coatsworth

Christopher Coe

Pamela Cole

Meredith Coles

Rand Conger

Martha Cox

E. Mark Cummings

J. J. Cutuli

Rina das Eiden

Jonathan Davidson

Tracy Dennis

Colin DeYoung

Joshua Diehl

Thomas Dishion

Caroline Donovan

John Eckenrode

Katie Ehrlich

Inge-Marie Eigsti

Nancy Eisenberg

Mona El-Sheikh

Marilyn Essex

Erika Forbes

Abi Gewirtz

Sharon Glennen

\author{
Vivette Glover \\ Elana Gordis \\ Julia Graber \\ Isabella Granic \\ Kathryn Grant \\ Mark Greenberg \\ Andrea Greenhoot \\ John Grych \\ Megan Gunnar \\ Benjamin Hankin \\ Todd Hare \\ Ahmad Hariri \\ Cynthia Huang-Pollock \\ Diane Hughes \\ Carroll Izard \\ Kristie Jackson \\ Jennifer Jester \\ Ernest Jouriles \\ Julie Kaplow \\ Canan Karatekin \\ Annette Karmiloff-Smith \\ Margaret Keiley \\ Kathryn Kerns \\ Eva Kimonis \\ Erin Kinnally \\ Roger Kobak \\ Hans Koot \\ Sue Leekam \\ Alytia Levendosky \\ Richard Linscott \\ Joan Luby \\ Monica Luciana \\ Beatriz Luna \\ Kim MacLean \\ Katharina Manassis \\ Gayla Margolin \\ Peter Marshall \\ Carrie Masten \\ Kai McCormack \\ James McHale
}


Judi Mesman

Stephanie Meyer

David Miklowitz

Dianna Murray-Close

Misaki Natsuaki

Sarah Nelson

Erika Niwa

Jennie Noll

Jens Omli

Jamie Ostrov

Opal Ousley

Katherine Pears

Deborah Pepler

Joan Peskin

Erin Pickreign Stronach

David Pincus

Margaret-Ellen Pipe

Elysia Poggi Davis

Stephen Porges

Mitch Prinstein

Frances Rice

Sally Rogers

Mar Sanchez

Mary L. Schneider
John Schulenberg

Jen Silk

Nancy Snidman

Jennifer Tackett

Ralph Tarter

Amanda Tarullo

Eric Taylor

Essi Viding

Frank Vitaro

Lauren Wakschlag

Sarah Watamura

Carl Weems

Susan Weismer

Christine Wekerle

Laura Wilson

Michael Windle

Adam Winsler

Peter Wyman

Tuppett Yates

Charles Zeanah

Philip Zelazo 


\section{DEVELOPMENT AND \\ PSYCHOPATHOLOGY}

Cumulative Contents

Volume 22, 2010

EDITOR

Dante Cicchetti 
Editor

Dante Cicchetti

Mt. Hope Family Center,

University of Rochester and

Institute of Child Development

and Department of Psychiatry,

University of Minnesota

Associate Editors

Patrick Davies

University of Rochester, USA

Stephen Hinshaw

University of California, Berkeley, USA

Suniya Luthar

Columbia University, USA

David Magnusson

University of Stockholm, Sweden

Ann Masten

University of Minnesota, USA

Fred A. Rogosch

Mt. Hope Family Center.

University of Rochester, USA

Michael Rutter

Institute of Psychiatry, London, UK

Ronald Seifer

Brown University, USA

Daniel Shaw

University of Pittsburgh, USA

L. Alan Sroufe

University of Minnesota, USA

Sheree L. Toth

Mt. Hope Family Center,

University of Rochester, USA

Elaine Walker

Emory University, USA

Editorial Board

Adrian Angold

Duke University Medical Center, USA

Carrie Bearden

University of California, Los Angeles, USA

Marjorie Beeghly

Children's Hospital, Boston, USA

Jay Belsky

University of London, $U K$

Francine M. Benes

Harvard Medical School. USA

Jacob Burack

Mc Gill University, Canada

Susan Calkins

University of North Carolina, USA

Susan Campbell

University of Pittsburgh, USA

Tyrone Cannon

University of California, Los Angeles, USA

E. Jane Costello

Duke University Medical Center, USA

Eric Courchesne

Children's Hospital Research Center

San Diego, USA

Nicki R. Crick

University of Minnesota, USA

Michael DeBellis

Duke University Medical Center, USA

Doug Derryberry

Oregon State University, USA

Byron Egeland

University of Minnesota, USA

Peter Fonagy

The Menninger Clinic, USA and

University College, London, UK

Cynthia Garcia Coll

Brown University, USA

Xiaojia Ge

University of Minnesota, USA

Douglas Granger

Pernsylvania State University, USA

Elena Grigorenko

Vale University, USA

Nicholas Ialongo

Johns Hopkins University, USA

Sara Jaffe

Institute of Psychiatry, London, UK

Mark Johnson

Birkheck College, London, UK
Canan Karatekin

University of Minnesofa, USA

Jungmeen Kim

Virginia Tech, USA

Julia Kim-Cohen

Yale University, USA

Bonnie Klimes-Dougan

University of Minnesota, USA

Mark Lenzenweger

SUNY Binghamton, USA

Alicia Lieberman

San Francisco General Hospital, USA

Sonia Lupien

McGill University, Canada

Donald Lynam

Purdue University, USA

Michael Lynch

SUNY Geneseo, USA

Jenny Macfic

University of Tennessee, USA

Robert Keith McBurnett

University of California, San Francisco, USA

Erin B. McClure-Tone

Georgia State University, USA

Ellen Moss

University of Quebec, Montreal, Canada

Eun Young Mun

Rutgers University, USA

Peter Mundy

University of Miami, USA

Jenae Neiderhise

Pennsylvania State University, USA

Joel Nigg

Michigan State University, USA

Thomas G. O'Connor

University of Rochester, USA

Daniel Pine

National Institute of Mental Health, USA

Robert Plomin

Institute of Psychiatry, London, UK

Seth Pollak

University of Wisconsin, Madison, USA

Michael Posner

University of Oregon, USA

Robert M. Post

National Institute of Mental Health, USA

Frank Putnam

University of Cincinnati, USA

Richard Rende

Brown University, USA

Sally Rogers

University of California, Davis, USA

Mary K. Rothbart

University of Oregon, USA

Karen Rudolph

University of Illinois at Urbana-Champaign, USA

Richard Ryan

University of Rochester, USA

John Schulenberg

University of Michigan, USA

Elizabeth A. Shirtcliff

University of Wisconsin, Madison, USA

James Snyder

Wichita State University, USA

Margaret Beale Spencer

University of Chicago, USA

Melissa Sturge-Apple

Mt. Hope Family Center,

University of Rochester, USA

Eric Taylor

Institute of Psychiatry, London, UK

Jody Todd Manly

Mt. Hope Family Center,

University of Rochester, USA

Don Tucker

University of Oregon, USA

Brian Vaughn

Auburn University, USA

Helena Verdeli

Teachers College, Columbia University, USA

Irwin Waldman

Emory University, USA

Daniel Weinberger

National Institute of Mental Health, USA

Robert Zucker

University of Michigan, USA
DEVELOPMENT AND PSYCHOPATHOLOGY

Aims and Scope: Development and Psychopathology is an international multidisciplinary journal devoted to the publication of original empirical, theoretical, and review articles on the interrelationship of normal and pathological development in children and adults.

\section{Editorial Office:}

Mt. Hope Family Center, University of Rochester

187 Edinburgh Street, Rochester, NY 14608

Telephone: (585) 275-2991

E-mail: developmentandpsychopathology@ rochester.edu

Publishing, Production, and Advertising Office:

Cambridge University Press, 32 Avenue of the Americas, New York, NY 10013-2473.

Subscription Offices: (for USA, Canada, and Mexico) Cambridge University Press, 32 Avenue of the Americas, New York, NY 10013-2173; (for UK and elsewhere) Cambridge University Press, The Edinburgh Building, Shaftesbury Road, Cambridge CB2 8RU, UK

2010 Subscription Information: Development and Psychopathology (ISSN 0954-5794) is published quarterly by Cambridge University Press, 32 Avenue of the Americas, New York, NY 10013-2473, USA/Cambridge University Press, The Edinburgh Building, Shaftesbury Road, Cambridge CB2 8RU, UK. Annual subscription rates: Institutions print and electronic: US\$494 in the USA. Canada, and Mexico; UK £265 + VAT elsewhere. Institutions electronic only: US $\$ 421$ in the USA Canada, and Mexico; UK $\$ 229+$ VAT elsewhere. Institutions print only: US \$458 in the USA, Canada, and Mexico; UK $£ 250$ + VAT elsewhere. Individuals print and electronic: US $\$ 153$ in the USA, Canada, and Mexico; UK $£ 83+$ VAT elsewhere. Individuals print only: US \$125 in the USA, Canada, and Mexico; UK $£ 75+$ VAT elsewhere. Single Part: US $\$ 114$ in the USA, Canada, and Mexico; UK $£ 62+$ VAT elsewhere. Prices include postage and insurance. Airmail or registered mail is extra. Back volume prices are available upon request.

Institutional Subscribers: Information on Development and Psychopathology and all other Cambridge journals is available at the Cambridge Journals Online website via http://www.journals.cambridge.org

Indexing: This journal is covered in Child Development Abstracts \& Biblingraphy, Current Contents/Social \& Behavioral Sciences Social Sciences Citation Index, Index Medicus, and MEDLINE.

(c) Cambridge University Press 2010. All rights reserved. No part of this publication may be reproduced, in any form or by any means, electronic, photocopy, or otherwise, without permission in writing from Cambridge University Press. For further information see http://us.cambridge.org/information/rights or http:/www.cambridge.org/uk/information/rights

Photocopying Information (for USA only): The Item-Fee Code for this publication (0954-5794/10 \$20.00) indicates that copying for internal or personal use beyond that permitted by Sec. 107 or 108 of the US Copyright Law is authorized for users duly registered with the Copyright Clearance Center (CCC), provided that the appropriate remittance per article is paid directly to: CCC, 222 Rosewood Drive, Danvers, MA 01923. Specific written permission must be obtained for all other copying; contact the nearest Cambridge University Press office. Contact the ISI Tearsheet Service, 3501 Market Street, Philadelphia, PA 19104 , for single copies of separate articles.

Periodicals postage is paid at New York, NY, and additional mailing offices. POSTMASTER: Send address changes in the USA,

Canada, and Mexico to: Development and Psychopathology, Cambridge University Press, 100 Brook Hill Drive, West Nyack, NY 10994-2133.

Printed in the United States of America. 


\section{Contents to Volume 22}

\section{Volume 22}

HILARY K. MEAD, Theodore P. BEAUChaine, AND Katherine E. SHANNON

GINGER A. Moore

ERIN L. KINNALLY, Genesio M. KARERE,

LESLIE A. LyONS,

Sally P. Mendoza,

William A. Mason, AND JOHN P. CAPITANIO

MAR M. SANCHEZ, KAI MCCORMACK, AlisOn P. GRAND, RiCHELLE FULKS,

ANNE GRAFF, AND

DARIO MAESTRIPIERI

JENNIFER RICHLER, MARisela Huerta,

SOMER L. BISHOP, AND CATHERINE LORD

SALLY J. ROGERS, GREGORY S. YOUNG, IAN COOK,

Angelo Giolzetti, AND SALLy OZONOFF

CHANTAL Cyr,

EVELINE M. EUSER,

MARIAN J. BAKERMANS-KRANENBURG, AND MARINUS H. VAN IJZENDOORN

MiRJAM OOSTERMAN, J. CLASIEN DE SCHIPPER,

PHILIP FISHER, MARY DOZIER, AND CARLo SCHUENGEL

ALYSIA Y. BLANDON, SUSAN D. CALKINS, and Susan P. Keane

Susan B. CAMPBEll, SUSAN SPIEKER,

NATHAN VANDERGRIFT, JAY BELSKY,

MARGARET BURCHINAL, AND

THE NICHD EARLy CHILD

CARE Research Network

\section{February 2010}

Number 1

\section{CONTENTS}

Articles

1 Neurobiological adaptations to violence across development

23 Parent conflict predicts infants' vagal regulation in social interaction

35 Serotonin pathway gene-gene and gene-environment interactions influence behavioral stress response in infant rhesus macaques

45 Effects of sex and early maternal abuse on adrenocorticotropin hormone and cortisol responses to the corticotropin-releasing hormone challenge during the first 3 years of life in group-living rhesus monkeys

55 Developmental trajectories of restricted and repetitive behaviors and interests in children with autism spectrum disorders

71 Imitating actions on objects in early-onset and regressive autism: Effects and implications of task characteristics on performance

87 Attachment security and disorganization in maltreating and high-risk families: A series of meta-analyses

109 Autonomic reactivity in relation to attachment and early adversity among foster children

119 Predicting emotional and social competence during early childhood from toddler risk and maternal behavior

133 Predictors and sequelae of trajectories of physical aggression in school-age boys and girls 
Alithe L. van Den Akker,

MAJA DeKOVIĆ, AND PETER PRINZIE

Penelope K. Trickett, JENNIE G. NOLL, ElizABETH J. SUSMAN,

ChAD E. SHENK, AND

FRANK W. PUTNAM

LAURA E. BRUMARIU AND KATHRYN A. KERNS

Julia Felton, David A. Cole,

Carlos Tilghman-Osborne, and Melissa A. MaXwell

BENJAMIN L. HANKIN,

LindSEy Stone, AND

PATRICIA ANN Wright

MEgan R. GUNNAR, SANDI WEWERKA,

KRISTIN FRENN, JEFFREY D. LONG, AND

Christopher GrigGS

\section{Volume 22}

SONYA K. STERBA AND DANIEl J. BAUER

Peter C. M. MolenaAR

Eun Young Mun, Marsha E. Bates, AND EVGENY VASCHILLO

Nicholas IALONGO

AleXANDER VON Eye
151 Transitioning to adolescence: How changes in child personality and overreactive parenting predict adolescent adjustment problems

165 Attenuation of cortisol across development for victims of sexual abuse

177 Parent-child attachment and internalizing symptoms in childhood and adolescence: A review of empirical findings and future directions

205 The relation of weight change to depressive symptoms in adolescence

217 Corumination, interpersonal stress generation, and internalizing symptoms: Accumulating effects and transactional influences in a multiwave study of adolescents

\section{Corrigendum}

237 Developmental changes in hypothalamic-pituitary-adrenal activity over the transition to adolescence: Normative changes and association with puberty

\section{May 2010}

Number 2

\section{CONTENTS}

Special Section Articles

Keynote Article

239 Matching method with theory in person-oriented developmental psychopathology research

\section{Commentaries}

255 Testing all six person-oriented principles in dynamic factor analysis

261 Closing the gap between person-oriented theory and methods

273 Steps substantive researchers can take to build a scientifically strong case for the existence of trajectory groups

277 Developing the person-oriented approach: Theory and methods of analysis 
SONYA K. STERBA AND DANIEl J. BAUER

GLENN I. RoISMAN, KATHRYN C. MONAHAN, SuSAN B. CAMPBELL, LAURENCE STEINBERG, Elizabeth Cauffman, AND The NATional Institute OF Child Health and Human Development Early Child Care Research Network

STEPHANIE T. LANZA, BRITTANY L. RHOADES, ROBERT L. NIX,

MARK T. GREENBERG, AND

The Conduct Problems Prevention Research Group

KAREN APPLEYARD, ChONGMing YANG, AND

DESMOND K. RUNYAN

Atsushi Senju, Victoria SOUTHGATE, YUI MiURA, TOMOKO MATSUI, TOSHIKAZU HASEGAWA, YOSHIKUNI TOJO, Hiroo OSANAI, AND Gergely CSIBRA

StÉPHANE Duchesne, SimON LAROSE, FRANK VITARO, AND RICHARD E. TREMBLAY

BETSY HOZA, Dianna Murray-Close, L. EugEne ARNOLD, STEPHEN P. HINSHAW, LILY HECHTMAN, AND THE MTA COOPERATIVE GrouP

IDA MOADAB, TARA GILBERT, THOMAS J. DISHION, AND DON M. TUCKER
Authors' Response

287 Statistically evaluating person-oriented principles revisited

\section{Regular Articles}

295 Is adolescence-onset antisocial behavior developmentally normative?

313 Modeling the interplay of multilevel risk factors for future academic and behavior problems: A person-centered approach

337 Delineating the maladaptive pathways of child maltreatment: A mediated moderation analysis of the roles of self-perception and social support

353 Absence of spontaneous action anticipation by false belief attribution in children with autism spectrum disorder

361 Trajectories of anxiety in a population sample of children: Clarifying the role of children's behavioral characteristics and maternal parenting

375 Time-dependent changes in positively biased self-perceptions of children with attention-deficit/hyperactivity disorder: A developmental psychopathology perspective

391 Frontolimbic activity in a frustrating task: Covariation between patterns of coping and individual differences in externalizing and internalizing symptoms 
E. Mark Cummings, Christine E. MERRILEES, ALICE C. SCHERMERHORN, Marcie C. Goeke-Morey, PETER SHIRLOW, AND ED CAIRNS

VladimiR MisKovic, LOUIS A. SCHMIDT, Katholiki Georgiades, Michael BOyLE, AND HARRIET L. MACMILLAN

KAREN D. RUDOLPH AND WENDY TROOP-GORDON
405 Testing a social ecological model for relations between political violence and child adjustment in Northern Ireland

419 Adolescent females exposed to child maltreatment exhibit atypical EEG coherence and psychiatric impairment: Linking early adversity, the brain, and psychopathology

433 Personal-accentuation and contextual-amplification models of pubertal timing: Predicting youth depression

\section{CONTENTS}

Special Issue: Developmental Cascades: Part 1

Editorial

AnN S. Masten AND DANTE CICCHETTI

491

Developmental cascades

Articles

Martha J. COX, Roger Mills-Koonce, CATHI PROPPER, AND

JEAN-LOUIS GARIÉPY

NANCY EISENBERG, Tracy L. SpINRAD, Natalie D. EgGum, KASSONDRA M. SIlVA, MARK REISER, Claire Hofer, CYNTHIA L. SMITH, BRIDGET M. GAERTNER, ANNE KUPFER, TIERNEY POPP, AND Nicole MichaliK Chrystyna D. Kouros, E. Mark Cummings, AND PATRICK T. DAVIES

TUPPETT M. YATES, JELENA OBRADOVIĆ, AND BYRON EGELAND
497 Systems theory and cascades in developmental psychopathology

507 Relations among maternal socialization, effortful control, and maladjustment in early childhood

527 Early trajectories of interparental conflict and externalizing problems as predictors of social competence in preadolescence

539 Transactional relations across contextual strain, parenting quality, and early childhood regulation and adaptation in a high-risk sample 
KeIth B. BURT AND

GLENN I. RoISMAN

POL A. C. VAN LIER

and Hans M. KoOT

Xinyin Chen, XiaOrui Huang,

LEI CHANG,

LI WANG,

AND DAN LI

JENNIFER E. LANSFORD, PAtrick S. Malone, Kenneth A. Dodge, GREGORY S. PETTIT, AND JOHN E. BATES

Thomas J. Dishion, MARIE-HÉlÈne VÉRONNEAU, AND Michael W. Myers

JeLENA OBRAdović AND ALISON HIPWELl

KRISTIN L. MoILANEN, Daniel S. SHaw, AND KARI L. MAXWELL

TODD I. HERRENKOHL, Rick Kosterman, W. Alex Mason, J. DAVID Hawkins,

Carolyn A. McCarty, and Elizabeth McCAULEY

Gene H. BRody, YI-Fu CHEN, AND Steven M. Kogan

Ann S. Masten, Christopher David Desjardins, CHRISTOPHER M. MCCORMICK, SAlly I-Chun KuO, AND JEFFREY D. LONG

Monica J. MARTin, RAND D. CONGER, THOMAS J. SCHOFIELD, SHANNON J. DOGAN, KEITH F. WIDAMAN, M. BRENT DonNELlan, AND TRICIA K. NEPPL
557 Competence and psychopathology: Cascade effects in the NICHD Study of Early Child Care and Youth Development

569 Developmental cascades of peer relations and symptoms of externalizing and internalizing problems from kindergarten to fourth-grade elementary school

583 Aggression, social competence, and academic achievement in Chinese children: A 5-year longitudinal study

593 Developmental cascades of peer rejection, social information processing biases, and aggression during middle childhood

603 Cascading peer dynamics underlying the progression from problem behavior to violence in early to late adolescence

621 Psychopathology and social competence during the transition to adolescence: The role of family adversity and pubertal development

635 Developmental cascades: Externalizing, internalizing, and academic competence from middle childhood to early adolescence

655 Effects of childhood conduct problems and family adversity on health, health behaviors, and service use in early adulthood: Tests of developmental pathways involving adolescent risk taking and depression

667 A cascade model connecting life stress to risk behavior among rural African American emerging adults

679 The significance of childhood competence and problems for adult success in work: A developmental cascade analysis

695 Evaluation of the interactionist model of socioeconomic status and problem behavior: A developmental cascade across generations 
BRENT W. ROBERTS, JOSHUA J. JACKSON, JESSICA M. BERGER, AND ULRICH TRAUTWEIN

\section{Corrigendum}

715 Conscientiousness and externalizing psychopathology: Overlap, developmental patterns, and etiology of two related constructs

\section{CONTENTS}

Special Issue: Developmental Cascades: Part 2

\author{
MARC H. BORNSTEIN, \\ Chun-Shin Hahn, AND \\ O. Maurice Haynes \\ Alysia Y. Blandon, \\ SUSAN D. CALKINS, \\ KeVIN J. GRIMM, \\ Susan P. Keane, \\ and MARION O'BRIEN \\ WILLIAM M. BUKOWSKI, \\ BRETT LaURSEN, \\ AND BETSY HoZA \\ Selva Lewin-Bizan, \\ EDMOND P. BOWERS, \\ AND RICHARD M. LERNER \\ Darya Bonds McClain, \\ SHARLENE A. WOLCHIK, \\ EMILY WINSLOW, \\ JENN-YUN TEIN, \\ IRWIN N. SANDLER, \\ AND Roger E. Millsap \\ Dianna Murray-Close, \\ BETSY HOZA, \\ STEPHEN P. Hinshaw, \\ L. Eugene ARNold, \\ JAMES SWANSON, \\ Peter S. Jensen, \\ LILY HeChTMAN, \\ and KaREN Wells \\ Caroline K. Pemberton, \\ JENAE M. NEIDERHISER, \\ LESLIE D. LEVE, \\ MisAKI N. NATSUAKI, \\ DANIEL S. SHAW, \\ DAVID REISS, \\ and Xiaojia Ge
}

Articles

717 Social competence, externalizing, and internalizing behavioral adjustment from early childhood through early adolescence: Developmental cascades

737 Testing a developmental cascade model of emotional and social competence and early peer acceptance

749 The snowball effect: Friendship moderates escalations in depressed affect among avoidant and excluded children

759 One good thing leads to another: Cascades of positive youth development among American adolescents

771 Developmental cascade effects of the New Beginnings Program on adolescent adaptation outcomes

785 Developmental processes in peer problems of children with attention-deficit/hyperactivity disorder in The Multimodal Treatment Study of Children With ADHD: Developmental cascades and vicious cycles

803 Influence of parental depressive symptoms on adopted toddler behaviors: An emerging developmental cascade of genetic and environmental effects 
JUDY GARBER

And David A. Cole

ERIN C. TULLY,

WiLliam G. IACONO, AND Matt McGue

Bonnie KLIMES-Dougan, JEFFREY D. LONG, Chim-Yuan Steven Lee, DonNa S. RONSAVILLE, PhILIP W. GOLD, AND Pedro E. Martinez

MARK F. LENZENWEGER

Fred A. Rogosch, ASSAF OSHRI, AND

DANTE CicChetTI

MOIRA HALLER, Elizabeth HANDLEY, LAURIE CHASSIN, AND KAITLIN BOUNTRESS

JEREMY STAFF, JoHn E. SCHULENBERG, Julie MasLOWSKY, JERALD G. BACHMAN, PATRICK M. O'MALlEy, JENNIFER L. MAGGS, AND LLOYD D. JOHNSTON

SARAH D. LyNNE-LANDSMAN, Catherine P. Bradshaw, AND Nicholas S. IALONGO

Gerald R. PatTerson, MARION S. Forgatch, AND David S. DeGarmo

EDWARD P. MuLVEy, LAURENCE STEINBERG,

Alex R. PiQuero,

Michelle BesAnA, JEFFREY FAGAN, CAROL SCHUBERT, AND ELIZABETH CAUFFMAN
819 Intergenerational transmission of depression: A launch and grow model of change across adolescence

831 Changes in genetic and environmental influences on the development of nicotine dependence and major depressive disorder from middle adolescence to early adulthood

849 Continuity and cascade in offspring of bipolar parents: A longitudinal study of externalizing, internalizing, and thought problems

867 A source, a cascade, a schizoid: A heuristic proposal from The Longitudinal Study of Personality Disorders

883 From child maltreatment to adolescent cannabis abuse and dependence: A developmental cascade model

899 Developmental cascades: Linking adolescent substance use, affiliation with substance use promoting peers, and academic achievement to adult substance use disorders

917 Substance use changes and social role transitions: Proximal developmental effects on ongoing trajectories from late adolescence through early adulthood

933 Testing a developmental cascade model of adolescent substance use trajectories and young adult adjustment

949 Cascading effects following intervention

\section{Corrigendum}

971 Trajectories of desistance and continuity in antisocial behavior following court adjudication among serious adolescent offenders

973 Volume 22 Reviewers

977 Volume 22 Cumulative Contents 
Development and Psychopathology strongly encourages contributions from a wide array of disciplines because an effective developmental approach to psychopathology necessitates a broad synthesis of knowledge. Manuscripts will be considered that address, for example, the causes and effects of genetic, neurobiological, biochemical, cognitive, or socioemotional factors in developmental processes with relevance to various risk or psychopathological conditions. The journal also seeks articles on the processes underlying the adaptive and maladaptive outcomes in populations at risk for psychopathology.

\section{Manuscript Review Policy}

Manuscripts will have a blind review by at least two scholars. Every effort will be made to notify authors within 90 days of submission concerning the reviewers' recommendations and comments. Development and Psychopathology has no page charges.

\section{Manuscript Submission and Review}

All manuscript submissions to Development and Psychopathology must be made electronically via ScholarOne Manuscripts:

http://mc.manuscriptcentral.com/dpp

Please follow the complete instructions on this website to avoid delays. The instructions will prompt the author to provide all necessary information, including the corresponding author's contact information, which includes complete mailing address, phone and fax numbers, and an e-mail address. The website also requests suggested reviewers. The website will automatically acknowledge receipt of the manuscript and provide a manuscript reference number. The Editorin-Chief will assign the manuscript to an Editor who will choose at least two other reviewers. Every effort will be made to provide the author with a rapid review. If the Editor requests that revisions be made to the manuscript before publication, a maximum of 3 months will be allowed for preparation of the revision. For additional information on the new online submission and review system, please read the Tutorial for Authors or the Tutorial for Reviewers available from ScholarOne Manuscripts.

\section{Manuscript Preparation and Style}

General. All manuscripts must be provided in MSWord or PDF format in 12-point type with 1-in. margins on all sides. The entire manuscript must be double-spaced and numbered consecutively. The language of publication is English.

Style and Manuscript Order. Follow the general style guidelines set forth in the Publication Manual of the American Psychological Association (5th ed.). The Editor may find it necessary to return manuscripts for reworking or retyping that do not conform to requirements. Do not use embedded references, end notes, or bookmarks. Manuscripts must be arranged in the following order:

Title Page (page 1). To facilitate blind review, all indication of authorship must be limited to this page; other pages must only show the short title plus page number at the top right. The title page should include the (a) full article title; (b) name and affiliations of all authors; (c) acknowledgments; (d) mailing address and telephone number of the corresponding author; (e) address of where to send offprints, if different from the corresponding author; and (f) a short title of less than 50 characters.

Acknowledgments (page 1). These should be placed below the affiliations. Use this section to indicate grant support, substantial assistance in the preparation of the article, or other author notes.
Abstract Page (page 2). Include (a) a full article title, (b) an abstract of no more than 200 words, and (c) up to five keywords for indexing and information retrieval.

Text (page 3). Use a standard paragraph indent. Do not hyphenate words at the ends of lines or justify right margins.

References. Bibliographic citations in the text must include the author's last name and date of publication and may include page references. Examples of in-text citation style are Cicchetti (2002), Durston (2008, pp. 1133-1135), Hunt and Thomas (2008), (Hunt \& Thomas, 2008), (Posner, Rothbart, Sheese, \& Tang, 2007), and subsequently (Posner et al., 2007). If more than one, citations must be in alphabetical order. Every in-text citation must be included in the reference section; every reference must be cited in the text. Examples of reference styles:

\section{Journal Article}

Cicchetti, D., \& Thomas, K. M. (2008). Imaging brain systems in normality and psychopathology. Development and Psychopathology, 20, 1023-1027.

\section{Book}

Piaget, J. (1962). Play, dreams, and imitation in childhood. New York: Norton.

\section{Chapter in an Edited Book}

Gottlieb, G., \& Willoughby, M. T. (2006). Probabilistic epigenesis of psychopathology. In D. Cicchetti \& D. Cohen (Eds.), Developmental psychopathology (Vol. 1, 2nd ed., pp. 673-700). New York: Wiley.

Appendix (optional). Use only if needed.

Tables. Tables must appear as a unit following the reference section. Each table should be typed double-spaced on a separate page, numbered consecutively with an Arabic numeral, and given a short title (e.g., Table 5. Comparisons on language variables). All tables must be cited in the text.

Figures. Figures must appear as a unit following the tables. Each figure must be numbered consecutively with an Arabic numeral and a descriptive legend. Legends must be provided separately from the artwork (e.g., Figure 3. The progress in language development). Figures, which are normally in black and white, should be no larger than $6 \times 9$ in. and placed within the manuscript file. If authors have print color figures, Cambridge will provide a price quotation for the cost to the author. Online-only color is provided free of cost. Diagrams must be computer generated. All labels and details must be clearly presented and large enough to remain legible at a 50\% reduction. Artwork should be identified by figure number and short title. All figures must be cited in the text.

\section{Copyediting and Page Proofs}

The publisher reserves the right to copyedit manuscripts to conform to journal style. The corresponding author will receive page proofs for correction of typographical errors only. No rewriting of the original manuscript as submitted is allowed in the proof stage. Authors must return proofs to Cambridge within $48 \mathrm{hr}$ of receipt or approval will be assumed.

\section{Offprints}

The corresponding author will receive a free high-quality PDF of his or her article. A form accompanying the page proofs allows the 
corresponding author to order complete copies of the issue and/or purchase offprints. All coauthor offprint requirements must be included on this form. Orders received after the issue is printed are subject to a 50\% reprint surcharge.

\section{Copyright and Originality}

It is a condition of publication that all manuscripts submitted to this journal have not been published and will not be simultaneously submitted or published elsewhere. All authors must sign the Transfer of Copyright Agreement, which is available from ScholarOne Manuscripts, before an article can be published. Government authors whose articles were created in the course of their employment must so certify in lieu of copyright transfer. Authors must obtain written permission from the copyright owners to reprint any previously published material included in their article and provide the permissions to Cambridge University Press. 


\section{Corrigendum}

EDWARD P. MULVEY,

971 Trajectories of desistance and continuity in antisocial behavior following court adjudication among serious adolescent offenders

Alex R. Piquero,

Michelle Besana,

JEFFREY FAGAN,

CAROL SCHUBERT, AND

Elizabeth CAUfFMAN

973 Volume 22 Reviewers

977 Volume 22 Cumulative Contents 


\section{Caroline K. Pemberton, JENAE M. NEIDERHISER, Leslie D. LEVE, MisAKI N. NATSUAKI, Daniel S. Shaw, DAVID REISS, and Xiaojia Ge \\ JUDY GARBER AND David A. Cole \\ ERIN C. TULLY, WiLLIAM G. IACONO, AND Matt McGue}

BonNie KLIMES-Dougan, JEFFREY D. LONG, Chim-Yuan Steven Lee, Donna S. Ronsaville, PHILIP W. GOLD, AND Pedro E. Martinez

MARK F. LENZENWEGER

Fred A. Rogosch, ASSAF OSHRI, AND

DANTE CicchetTI

MOIRA HALLER, ElizABETH HANDLEY, LAURIE CHASSIN, AND KAITLIN BOUNTRESS

JEREMY STAFF, JoHn E. SCHULENBERG, JULIE MASLOWSKY, JERALD G. BACHMAN, PATRick M. O'MALley, JENNIFER L. MAGGS, AND LLOYD D. JOHNSTON

SARAH D. LYNNE-LANDSMAN, CATHERINE P. BRADShaW, AND NichOLAS S. IALONGO

GERALD R. PATTERSON, MARION S. FORGATCH, AND DAVID S. DEGARMO
803 Influence of parental depressive symptoms on adopted toddler behaviors: An emerging developmental cascade of genetic and environmental effects

819 Intergenerational transmission of depression: A launch and grow model of change across adolescence

831 Changes in genetic and environmental influences on the development of nicotine dependence and major depressive disorder from middle adolescence to early adulthood

849 Continuity and cascade in offspring of bipolar parents: A longitudinal study of externalizing, internalizing, and thought problems

867 A source, a cascade, a schizoid: A heuristic proposal from The Longitudinal Study of Personality Disorders

883 From child maltreatment to adolescent cannabis abuse and dependence: A developmental cascade model

899 Developmental cascades: Linking adolescent substance use, affiliation with substance use promoting peers, and academic achievement to adult substance use disorders

917 Substance use changes and social role transitions: Proximal developmental effects on ongoing trajectories from late adolescence through early adulthood

933 Testing a developmental cascade model of adolescent substance use trajectories and young adult adjustment 


\section{DEVELOPMENT AND PSYCHOPATHOLOGY}

Volume 22

November 2010

Number 4

\section{CONTENTS}

Special Issue: Developmental Cascades: Part 2

Marc H. Bornstein, Chun-Shin HAHN, AND O. Maurice Haynes

Alysia Y. Blandon, Susan D. CALKINS, KEVIN J. GRIMM, Susan P. KeAne, AND Marion O'BRIEN

WiLLIAM M. BuKOWSKI, BRETT LAURSEN, AND BETSY HozA

Selva Lewin-Bizan, EDMOND P. BOWERS, AND RICHARD M. LERNER

DARYA BoNDS MCClain, SHARLENE A. WOLChIK, EMILY WinsLOW, JENN-YUn TEIN, IRWIN N. SANDLER, AND Roger E. MiLlsaP

Dianna Murray-Close, BETSY HoZA, STEPHEN P. Hinshaw, L. Eugene ARNOLD, JAMES SWANSON, Peter S. Jensen, LiLY HeChTMAN, AND KAREN WeLls

\section{Articles}

717 Social competence, externalizing, and internalizing behavioral adjustment from early childhood through early adolescence: Developmental cascades

737 Testing a developmental cascade model of emotional and social competence and early peer acceptance

749 The snowball effect: Friendship moderates escalations in depressed affect among avoidant and excluded children

759 One good thing leads to another: Cascades of positive youth development among American adolescents

Developmental cascade effects of the New Beginnings Program on adolescent adaptation outcomes

Developmental processes in peer problems of children with attention-deficit/hyperactivity disorder in The Multimodal Treatment Study of Children With ADHD: Developmental cascades and vicious cycles 